\title{
Cloning and Characterization of Two Related Serotonergic Receptors from the Brain and the Reproductive System of Aplysia That Activate Phospholipase C
}

\author{
Xiao-Ching Li, , ${ }^{1,2, a}$ Jean-François Giot, ${ }^{1, b}$ Dietmar Kuhl, ${ }^{1,0}$ René Hen, ${ }^{2}$ and Eric R. Kandel ${ }^{1,2}$ \\ ${ }^{1}$ Howard Hughes Medical Institute and ${ }^{2}$ Center for Neurobiology and Behavior, College of Physicians and Surgeons \\ of Columbia University, New York, New York 10032
}

\begin{abstract}
Serotonin (5-HT) plays important roles in various behavioral and physiological processes in Aplysia californica. These include feeding, locomotion, circadian rhythm, learning and memory, synaptic plasticity, and synaptic growth. Serotonin modulates these various functions by interacting with different 5-HT receptor subtypes that are coupled to various second-messenger systems. We report here the isolation and characterization of the first two serotonergic receptors from Aplysia californica, Ap5- $\mathrm{HT}_{\mathrm{B} 1}$ and $\mathrm{Ap}_{\mathrm{P}}-\mathrm{HT}_{\mathrm{B} 2}$, using a strategy based on the amino acid sequence homology among G-protein-coupled biogenic amine receptors. $\mathrm{Ap5}-\mathrm{HT}_{\mathrm{B} 1}$ and $\mathrm{Ap5}-\mathrm{HT}_{\mathrm{B} 2}$ are both intronless and highly homologous to each other, sharing $79.5 \%$ sequence identity at the amino acid level. Sequence comparison reveals that these receptors are 33.1 to $23.3 \%$ identical to the following 5-HT receptors: $5-\mathrm{HT}_{\text {drot }}>5-\mathrm{HT}_{6}>$ $5-\mathrm{HT}_{\mathrm{Iym}}>$ mouse $5-\mathrm{HT}_{1 \mathrm{~B}}>5-\mathrm{HT}_{\text {dropA }}>$ mouse $5-\mathrm{HT}_{7}>$ rat $5-\mathrm{HT}_{2 \mathrm{~A}}$. Both Ap5- $\mathrm{HT}_{\mathrm{B} 1}$ and $\mathrm{Ap5}-\mathrm{HT}_{\mathrm{B} 2}$ encode functional 5-HT receptors. When expressed in cultured cells, these receptors stimulate phospholipase $C$ in response to $5-\mathrm{HT}$ in a dose-dependent manner. This stimulation can be blocked by specific 5-HT receptor antagonists. Using RTPCR and Western blot analysis, we have detected these receptors in the CNS $\left(\mathrm{Ap5}-\mathrm{HT}_{\mathrm{B} 2}\right)$ and in the reproductive system (Ap5-HT $\mathrm{B}_{\mathrm{B}}$ ). The nucleotide sequences of $\mathrm{Ap5}-\mathrm{HT} \mathrm{B}_{\mathrm{B1}}$ and $\mathrm{Ap}-\mathrm{HT}_{\mathrm{B} 2}$ were submitted to GenBank; the accession numbers are $L 43557$ and $L 43558$, respectively.
\end{abstract}

[Key words: cloning, Aplysia, serotonin, receptor, phospholipase C, nervous system, reproductive system]

Scrotonin is a neurotransmitter that is widely distributed in the animal kingdom. In mammals, 5-HT is involved in a variety of behaviors, including sleep, circadian rhythms, locomotion, ther-

\footnotetext{
Received Apr. 27, 1995; revised July 18, 1995; accepted July 20, 1995.

X.-C.L. and J.-F.G. have equally contributed to this work. The work was supported in part by the Howard Hughes Medical Institute (E.R.K. and X.C.L.). We thank Xue-Ying Cao, Tom Livelli, and Kevin Karl for technical assistance in preparing our experiments. We thank C. Lam for help with the figures and $\mathrm{A}$. Krawetz and $\mathrm{H}$. Ayers for typing the manuscript.

Correspondence should be addressed to Eric R. Kandel, M.D., Howard Hughes Medical Institute, 722 West 168th Street, New York, NY 10032.

aPresent address: The Rockefeller University, 1230 York Avenue, New York, New York 10021

'Present address: Max-Planck Institut für Biochemie, Am Klopferspitz 18A, 82152 Martinsried, Germany.

Present address: Center for Molecular Neurobiology (ZMNH), Hamburg University, Martinistrasse 52 (Pav.22), D-20246 Hamburg, Germany.

Copyright $(\mathrm{C} 1995$ Society for Neuroscience $0270-6474 / 95 / 157585-07 \$ 05.00 / 0$
}

moregulation, appetite control, pain perception, anxiety, emotion, and learning (Wilkinson and Dourish, 1991). Serotonin exerts its many physiological functions by binding to receptors such as the $5-\mathrm{HT}_{3}$ receptor that functions as a ligand-gated ion channel (Julius, 1992), or more commonly activates different second-messenger signaling pathways via G-protein-coupled receptors. The G-protein-coupled 5-HT receptors can be subgrouped into families: (1) those that stimulate or inhibit adenylyl cyclase to regulate cAMP $\left(5-\mathrm{HT}_{1 \mathrm{~A}}, 5-\mathrm{HT}_{1 \mathrm{~B}}, 5-\mathrm{HT}_{1 \mathrm{D}}, 5-\mathrm{HT}_{1 \mathrm{E}}\right.$, $5-\mathrm{HT}_{1 \mathrm{~F}}, 5-\mathrm{HT}_{4}, 5-\mathrm{HT}_{6}$, and 5- $\left.\mathrm{HT}_{7}\right)$; and (2) those that are coupled to phospholipase $\mathrm{C}$ to stimulate phosphoinositide metabolism $\left(5-\mathrm{HT}_{2 \mathrm{~A}}, 5 \mathrm{H}-\mathrm{T}_{2 \mathrm{~B}}\right.$, and $5-\mathrm{HT}_{2 \mathrm{C}}$ ) (see review by Hen et al., 1993; Hoyer et al., 1994).

In the invertebrate animal Aplysia californica, 5-HT plays important roles in divcrsc animal behaviors, such as feeding, locomotion, circadian rhythm, and simple forms of learning such as dishabituation, sensitization, and classical conditioning. Pharmacological and electrophysiological studies of the Aplysia nervous system have shown that 5 -HT is a modulatory neurotransmitter that acts on a variety of different receptors to activate different postsynaptic responses (Gerschenfeld and PaupardinTrich, 1974; Drummond et al., 1980; Kadan and Hartig, 1988). Moreover, 5-HT can elicit both short-term and long-term changes of the monosynaptic connections between sensory and motor neurons of the siphon- and gill-withdrawal reflex of Aplysia, a reflex that can be modulated by sensitization and classical conditioning (Kandel and Schwartz, 1982; Glanzman et al., 1989). These actions of 5-HT on the monosynaptic connections are likely to be mediated by different second messengers, and therefore quite likely via different 5 -HT receptors (Hochner et al., 1986; Baxter and Byrne, 1990; Braha el al., 1990; Mercer et al., 1991; Ghirardi et al., 1992; Emptage and Carew, 1993). In both short- and long-term changes, 5-HT activates cAMP and protein kinase A in the sensory neuron (Bacskai et al., 1993). Protein phosphorylation by PKA of ion channels causes an increase in membrane excitability and an increase in the duration of action potential, which lead to facilitation of transmitter release. Serotonin also leads to the activation of protein kinase $\mathrm{C}$ that in turn acts on ion channels and on the release machinery (Sawada ct al., 1989; Sacktor and Schwartz, 1990; Ghirardi et al., 1992). In addition to these short-term changes, PKA seems to act via CREB (Dash et al., 1990; Kaang et al., 1993) to stimulate the expression of immediate early genes such as C/EBP (Alberini et al., 1994), which can initiate a cascade of gene expression and subsequently lead to synaptic growth (Glanzman et al., 1990). 
As a first step toward a molecular characterization of these serotonergic receptors, and toward an understanding of their diverse physiological functions at the molecular and cellular level, we have begun to isolate 5-HT receptor genes from Aplysia. We describe here the cloning and characterization of two serotonin receptor genes, Ap5- $\mathrm{HT}_{\mathrm{B} 1}$ and $\mathrm{Ap5}-\mathrm{HT}_{\mathrm{B} 2}$. These two genes encode two highly related proteins that are members of the G-protein-coupled biogenic amine receptor family. Functional expression of these receptors in HEK-293 cells demonstrates that they activate phospholipase $\mathrm{C}$ in response to 5-HT. Using RT-PCR and Western blot analysis, we detected these receptors in the central nervous system (Ap5- $\mathrm{HT}_{\mathrm{B} 2}$ ) and reproductive system $\left(\mathrm{Ap} 5-\mathrm{HT}_{\mathrm{B} 1}\right)$.

\section{Materials and Methods}

$P C R$, genomic library construction, and screening. To prepare Aplysia genomic DNA we collected sperm from two $500 \mathrm{gm}$ animals and lysed them with $24 \mathrm{hr}$ of incubation at $50^{\circ} \mathrm{C}$ in PBS containing $0.5 \%$ SDS and $0.1 \mathrm{mg} / \mathrm{ml}$ Protease $\mathrm{K}$. After four consecutive phenol-chloroform extractions, the DNA was precipitated with ethanol and subsequently dissolved in TE buffer. One microgram of genomic DNA with $1 \mu \mathrm{g}$ of each of the two degenerate primer pools, 5'AAGAATTCTG(C,T)TGGTT(A,G)CCITT(T,C)TTT and 5'AAGCGGCCGCAGC(A,G)TA(A,G,T)ATIA(T,C)(A,C,G,T)GG(A,G)TT, corresponding to the sequences of transmembrane domain six and seven that are highly conserved among both mammalian and Drosophila biogenic amine receptors, were used in a PCR reaction. The PCR reaction was performed with $92^{\circ} \mathrm{C} / 1 \mathrm{~min}$ denaturing, $50^{\circ} \mathrm{C} / 1 \mathrm{~min}$ annealing, and $72^{\circ} \mathrm{C} / 2 \mathrm{~min}$ elongation for 30 cycles. The PCR products were then separated by electrophoresis. A DNA fragment of 102 base pairs (bp) was isolated, subcloned, and sequenced using the Sanger dideoxy chain termination method. This fragment was then used to screen the genomic library.

Aplysia genomic DNA was partially digested with the restriction enzyme MboI. DNA fragments of 15-20 kilobases (kb) in size were inserted into Lambda phage FixIl vector to generate the library (Stratagene). Hybridizations were performed to screen the genomic library in $50 \%$ formamide, $6 \times$ SSPE, $1 \%$ SDS, and $100 \mathrm{mg} / \mathrm{ml}$ salmon sperm DNA at $42^{\circ} \mathrm{C}$ for $20 \mathrm{hr}$. The filters were then washed in $2 \times \mathrm{SSC}-0.1 \%$ SDS for $2 \times 10 \mathrm{~min}$ at room temperature and in $1 \times$ SSC-0.1\% SDS for $2 \times 30 \mathrm{~min}$ at $55^{\circ} \mathrm{C}$. Positive clones were further purified, and amplified, and inserts were subcloned into Bluescript plasmid. Two independent clones were sequenced on both strands by standard didenxy chain termination method and analyzed with the computer program DNAStar.

Cell lines and second-messenger analysis. Mammalian expression vector pcDNAI or pcDNAIII (Invitrogen) were used to express functional receptors in tissue culture cell lines. The entire amino acid coding region of $\mathrm{Ap5}-\mathrm{HT}_{\mathrm{B}}$ (from $\mathrm{nt}-4$ to $\mathrm{nt}+1378$ ) was $\mathrm{PCR}$-amplified with restriction sites EcoRI attached to the 5'-end and NotI attached to the 3 '-end, and then subcloned into expression vector pcDNAI. For Ap5$\mathrm{HT}_{\mathrm{B} 2}$, the entire amino acid coding region (from nt -10 to $\mathrm{nt}+1440$ ) was PCR-amplified with restriction sites HindIII attached to the $5^{\prime}$-end and NotI attached to the $3^{\prime}$-end, and then subcloned into expression vector pcDNAIII. The recombinant plasmids were introduced into HEK-293 cells by calcium phosphate mediated transfection, and the transfected cells were selected under G418. Isolated foci were amplified and expression of the receptor gene was further confirmed by RNA Northern blot analysis. Cell lines expressing highest level of the receptor mRNA were used in the functional assays.

HEK-293 cells were labeled with ${ }^{3} \mathrm{H}$-myoinositol $(5 \mu \mathrm{Ci} / \mathrm{ml})$ for 48 hr. They were washed in PBS and aliquots of $5 \times 10^{5}$ cells were treated with various concentrations of testing drugs in PBS and $10 \mathrm{~mm} \mathrm{LiCl}$ for $30 \mathrm{~min}$ at room temperature. The reaction was stopped by adding $10 \% \mathrm{TCA}$ and the supernatant was further purified by a three time ether extraction to remove traces of TCA. Borax $(3 \mathrm{~mm})$ was added to adjust the $\mathrm{pH}$ and the sample was loaded to column prepacked with $2 \mathrm{ml}$ AG1X8: $\mathrm{H}_{2} \mathrm{O}(1: 1)$. The columns were successively washed with water and $5 \mathrm{~mm}$ Borax $/ 60 \mathrm{~mm}$ NaFormate. $\mathrm{IP}_{1}$ and $\mathrm{IP}_{2}$ were collected with 10 $\mathrm{ml}$ of $0.1 \mathrm{M}$ Formic Acid/0.4 M NH $\mathrm{N}_{4}$ Formate. $\mathrm{IP}_{3}$ was eluted with 10 $\mathrm{ml} 0.1 \mathrm{M}$ Formic Acid/1 M NH $\mathrm{N}_{4}$ Formate. The two fractions were then combined and subjected to scintillation counting.

$R T-P C R$ analysis. For the RT-PCR experiments, $100 \mathrm{ng}$ of mRNA isolated from various tissues as described in Micro-Fast Track (Invitrogen) were treated with RNAse-free DNAse I for $30 \mathrm{~min}$ to remove residual genomic DNA. After a phenol chloroform extraction, the RNA was precipitated with ethanol and Ammonium $\Lambda$ cetate. The RN $\Lambda$ was then resuspended in water containing an antisense primer common to both Ap- $\mathrm{HT}_{\mathrm{B} 1}$ and Ap5-HT ${ }_{\mathrm{B} 2}$ : 5'GCTGCTCGGAATTTGGAGTTGGACGTCCC, denaturated 10 min at $65^{\circ} \mathrm{C}$ and reverse transcribed al $42^{\circ} \mathrm{C}$ with AMV Reverse transcriptase (Invitrogen). One-tenth of the RT reaction was then subjected to 25 cycles of amplification with the following Ap5- $\mathrm{H}^{\prime} \mathrm{I}_{\mathrm{B} 1-\mathrm{B} 2}$ sense and antisense primers: $5^{\prime} \mathrm{CGCCTGAAGCAAG-}$ TTCAGAAGCCACT and 5'CATTCCAGTGGGATGAGGTGTTCAT$\mathrm{CT}$. One-fifth of the PCR reaction was analyzed by Southern blot with an Ap5-HT ${ }_{B 1}$ specific probe, 5'AGAAGAAAAATTGTGTGCTTCGAGGGCTTTTTCCTTTTCTGTTTTGTT, or an Ap5-HT $\mathrm{B}_{\mathrm{B} 2}$ specific probe, 5'AAAAGAAAAAGTGTGTGCGTCTGAGGTCTTCACCTTGTCAGAAATAAG. These oligonucleotides were ${ }^{32} \mathrm{P}$ labeled by kination and used for hybridization as decribed previously. Washings were performed at high stringency $(10$ min room temperature in $2 \times$ SSC $-0.1 \%$ SDS, $10 \mathrm{~min}$ at $55^{\circ} \mathrm{C}$ in $1 \times \mathrm{SSC}-0.1 \% \mathrm{SDS}$, and $10 \mathrm{~min}$ at $55^{\circ} \mathrm{C}$ in $0.5 \times$ SSC-0.1\% SDS).

Antibody production and immurnobloting. The Ap5- $\mathrm{HT}_{\mathrm{B} 1}$ sequence corresponding to the $\mathrm{C}$-terminal intracellular segment (starting from the amino acid FRAAFK, immediately following the seventh transmembrane domain and ending at the stop codon) was PCR amplified with restriction sites HindIII and NotI attached to each end, and then subcloned into fusion protein expression vector pMAL-C2 (New England Biolab) to produce maltose binding fusion protein. The fusion protein was purified on a maltose affinity column and subsequently inoculated into rabbits. Rabbits were boosted every 4 weeks and bled every 1 to 2 weeks after each boost. The serum was then collected, purified with the Pharmacia E-Z-SEP Kit, and tested for ELISA reactivity to the fusion protein. Crude tissue homogenates were prepared from Aplysia buccal muscle, CNS, heart, and ovotestis, electrophoresed on a $10 \%$ SDS polyacrylamide gel, and transferred to immobilon membrane. The membrane was blocked with blocking solution overnight at $4^{\circ} \mathrm{C}$ and then incubated with primary antibody for $1 \mathrm{hr}$ at room temperature. After washing, the membrane was incubated with peroxidase-labeled secondary antibody and a chemoilluminescence reaction was carried out to visualize the immunoactive bands. For antibody preabsorption, the antibody was incubated with $100 \mu \mathrm{g} / \mathrm{ml}$ fusion protein overnight at $4{ }^{\circ} \mathrm{C}$ before use.

\section{Results}

\section{Sequence analysis}

To isolate genes that encode Aplysia 5-H'T receptors, we performed PCR reactions on Aplysia genomic DNA using two degenerate primers deduccd respectively from the highly conserved transmembrane domain VI and VII of previously characterized G-protein-coupled biogenic amine receptors. A PCR product was analyzed and used as a probe to screen an Aplysia genomic library. Two different genomic clones, Ap5-HT $\mathrm{B}_{\mathrm{B} 1}$ and Ap5- $\mathrm{HT}_{\mathrm{B} 2}$, were isolated for further studies. The deduced amino acid sequences of genomic clones Ap5-HT $\mathrm{H}_{\mathrm{B} 1}$ and $\mathrm{Ap} 5-\mathrm{HT}_{\mathrm{B} 2}$ are

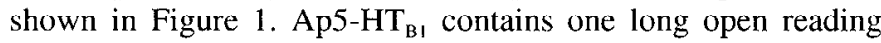
frame encoding a predicted protein of 453 amino acids. The hydropathy analysis of the deduced amino acid sequence reveals seven hydrophobic regions as putative transmembrane domains characteristic of $\mathrm{G}$-protein-coupled receptors. The relatively short third intracellular loop and the long C-terminal tail are features shared by the phospholipase $C$ linked biogenic amine receptors. On the amino acid sequence level, Ap5-HT $\mathrm{H}_{\mathrm{B} 1}$ contains several key features common to both mammalian and invertebrate serotonin receptors. For example, a canonical aspartic acid in the third transmembrane domain and a conserved serine in the fifth transmembrane domain probably are part of the binding site for serotonin. Others include a proline in the fifth transmembrane domain and the CWLPFF and WLGY conserved in the sixth and seventh transmembrane domains, respectively. Interestingly, instead of DRY as in all other serotonin receptors, a 
Ap5HTB1 MKSLKSSTHDVPHPEHVVWAPPAYDEQHHLFFSHGTVLIGIVGSLIITVA Ap5HTB2 MLCGRLRHTMNSTTCFFSHRTVLIGIVGSLIIAVS 一I- - II Ap5HTB1 Ap5HTB2 VVGNVLVCLAIFTEPILSHSKSNFFIVSLAVADLLLALLVMTFALVNDMY VVGNVLVCLAIFTEPILSHSKSKFFIVSLAVADLLLALLVMTFALVNSLY III

Ap5HTB1

Ap5HTB2

Ap5HTB1

Ap5HTB2

Ap5HTB1

Ap5HTB2

Ap5HTB1

Ap5HTB2

TNYLRLFLIAQTHQVRIRSLQMTNPPQLRGQGASSYRNQGTQGSKAARTL RNYLRLFLIAKKHHVRIKNLHRLH--.-------RNQGTQGSKAARTL

TIITGTFLACWLPFFIINPIAAADEHLIPLECFMVTIWLGYFNSSVNPII

Ap5HTB1

Ap5HTB2

Ap5HTB1

Ap5HTB2

YGTSNSKFRAAFKRLLRCRSVKSVVGSISPVSPAYRAFSWIRPSRLDLSS YGTSNSKFRAAFQRLLRCRSVKSTVSSISPVASVYRAFSWIRPSLLD---

Ap5HTB1

SEHPSDACDTGRGKNSKGGDCATADPTKPDVSVSEEI IYAGTKVFDSDTA -GPPSAVCDTGQDENRKGGGCVTTIPTESHVI ISEEEIRANVMLSESDTV
400

370

50

35

100

85

150

135

200

185

250

235

300

273

350

323

450 420
Ap5HTB1 FSS

Ap5HTB2 FS
Figure 1. Deduced amino acid sequences of the Aplysia genomic clone Ap5- $\mathrm{HT}_{\mathrm{B} 1}$ and $\mathrm{Ap} 5-\mathrm{HT}_{\mathrm{B} 2}$. The regions of sequence homology shared by Ap5$\mathrm{HT}_{\mathrm{B} 1}$ and $\mathrm{Ap} 5-\mathrm{HT}_{\mathrm{B} 2}$ are shaded. The putative seven transmembrane domains are indicated by lines at the top of the amino acid sequences and numbered $(I-V I I)$. Potential glycosylation sites are indicated by asterisks. Serines and threonine that are within the protein kinase $\mathrm{C}$ consensus sequence are indicated by dots.
DRL appears at the end of the third transmembrane domain. Furthermore, three $\mathrm{N}$-linked glycosylation sites were found in the second extracellular loop region. By contrast, such glycosylation sites for other mammalian and Drosophila serotonin receptors appear within the N-terminal extracellular domain. A total of three potential phosphorylation sites for protein kinase $\mathrm{C}$ were found, one of them within the C-terminal intracellular domain, which may contribute to the regulation of receptor sensitivity.

The second genomic clone, $\mathrm{Ap} 5-\mathrm{HT}_{\mathrm{B} 2}$, contains an open reading frame encoding a protein of 422 amino acids that is $80 \%$ identical to Ap5- $\mathrm{HT}_{\mathrm{B} 1}$, indicating that both proteins belong to the same family. The two proteins share $90 \%$ amino acid sequence homology within the transmembrane domains and adjacent regions, while the $\mathrm{N}$-terminal extracellular domains and the extracellular loops I and II are less conserved. More divergences occur within the large third intracellular loop and the C-terminal intracellular tail. It is likely that other Ap5-HT lated sequences are present in the Aplysia genome, since a genomic Southern blot probed with the coding region of Ap5-HT revealed a minimum of five distinct bands (data not shown).

The amino acid sequences of $\mathrm{Ap} 5-\mathrm{HT}_{\mathrm{B} 1}$ and $\mathrm{Ap} 5-\mathrm{HT}_{\mathrm{B} 2}$ are homologous to other G-protein-coupled mammalian and invertebrate serotonin receptors, particularly within the seven putative transmembrane domains and the adjacent sequences. In these regions, the homology between the $\mathrm{Ap} 5-\mathrm{HT}_{\mathrm{B} 1}$ and other serotonin receptors is: $33.1 \%$ to $5-\mathrm{HT}_{\text {drol }} ; 31.3 \%$ to rat $5-\mathrm{HT}_{6} ; 28 \%$ to $5-\mathrm{HT}_{\text {lym }} ; 27.3 \%$ to mouse $5-\mathrm{HT}_{1 \mathrm{~B}} ; 26.5 \%$ to $5-\mathrm{HT}_{\text {dro } 2 \mathrm{~A}} ; 25.8 \%$ to mouse $5-\mathrm{HT}_{7}$; and $23.3 \%$ to rat $5-\mathrm{HT}_{2 \mathrm{~A}}$ (Fig. $2 A$ ) However, dendrogram analysis of the amino acid sequences of the seven transmembrane domains and the adjacent regions of all the cloned 5-HT receptors indicates that $\mathrm{Ap} 5-\mathrm{HT}_{\mathrm{B} 1}$ and $\mathrm{Ap} 5-\mathrm{HT}_{\mathrm{B} 2}$ are only distantly related to the rest of the known 5-HT receptors (Fig. 2B). They cannot be readily grouped with any one of the previously described serotonin receptor subfamilies.

Ap5-HT $T_{B 1}$ and Ap5-HT $T_{B 2}$ receptors activate phospholipase $C$ in response to $5-H T$

To determine whether the genomic clones Ap5-HT $\mathrm{B}_{\mathrm{B} 1}$ and Ap5$\mathrm{HT}_{\mathrm{B} 2}$ encode functional receptors and to delineate the secondmessenger pathway they are coupled to, we subcloned the fulllength coding sequences of $\mathrm{Ap} 5-\mathrm{HT}_{\mathrm{B} 1}$ and $\mathrm{Ap} 5-\mathrm{HT}_{\mathrm{B} 2}$ into the mammalian expression vectors pcDNAI (Ap5- $\mathrm{HT}_{\mathrm{B} 1}$ ) and pcDNAIII (Ap5- $\mathrm{HT}_{\mathrm{B} 2}$ ), respectively. The recombinant plasmids were introduced into 293 cells by the calcium-phosphate-mediated transfection to establish cell lines in which Ap5-HT $\mathrm{B}_{\mathrm{B} 1}$ and $\mathrm{Ap} 5-\mathrm{HT}_{\mathrm{B} 2}$ receptors were stably expressed. We first tested the ability of different ligands to activate these receptors. In these cell lines there was no detectable change in cAMP level in response to serotonin, octopamine, tyramine, and dopamine within 
A

$$
\begin{aligned}
& \text { Ap5HTB2 } 90.5 \\
& \text { SHTIA rat } 25.5 \quad 24 \\
& \begin{array}{llll}
5 \mathrm{HT} 1 \mathrm{~B} \text { mou. } & 27.3 & 26.2 & 51.3
\end{array} \\
& \begin{array}{llll}
\text { SHTIF mou. } \quad 25.8 & 26.2 & 44.7
\end{array} \\
& \text { SHTdro2A } 26.5-26.5 \quad 42.2 \quad 40.4 \quad 41.8 \\
& \begin{array}{cccccc}
\text { SHT Lym } & 28 & 28 & 46.5 & 42.9 & 42.5
\end{array} \\
& \begin{array}{llllllll}
\text { SHTdrol } & 33.1 & 33.6 & 45.5 & 38.2 & 41.1 & 41.5 & 40.4
\end{array}
\end{aligned}
$$

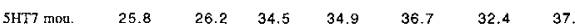

$$
\begin{aligned}
& \begin{array}{llllllll}
\text { 5HT7 mod. } & 25.8 & 26.2 & 34.5 & 34.9 & 36.7 & 32.4 & 37.1 \\
\text { 5HTSA mou. } & 23.6 & 22.9 & 34.5 & 32.7 & 33.8 & 34.5 & 30.5
\end{array} \\
& \begin{array}{llllll}
5 \text { 5HT rat } & 31.3 & 30.9 & 26.9 & 26.2 & 26.2
\end{array} \\
& \begin{array}{llllll}
\text { SHT2A rat } & 23.3 & 22.5 & 28.4 & 29.1 & 26.9
\end{array} \\
& \mathrm{ApB} 1 \quad \mathrm{ApB} 2 \quad 5 \mathrm{HT} 1 \mathrm{~A} \quad 5 \mathrm{HT} T \mathrm{~B}
\end{aligned}
$$

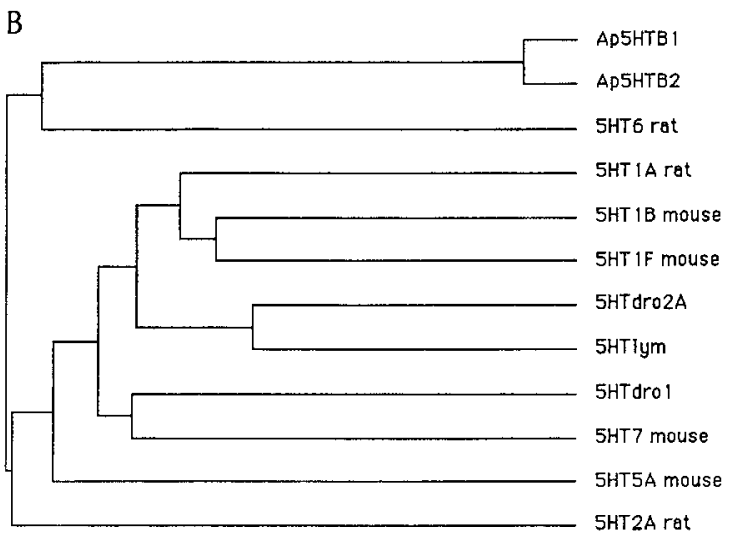

Figure 2. Amino acid sequence comparison between Ap5-HT $\mathrm{B}_{\mathrm{B}} / \mathrm{Ap5}$ $\mathrm{HT}_{\mathrm{B} 2}$ and other serotonin receptors. $A$, Percentages of amino acid sequence homology among different serotonin receptors. Calculations were based on the amino acid sequences of the seven transmembranc domains and the adjacent regions. $B$, Dendrogram analysis. The sequences of serotonin receptors were compared and clustered using the progran CLUSTAL. The lengths of the horizontal lines are inversely proportional to the percentages of homology between receptors or groups of receptors.

a wide dosage range (data not shown), and none of these agonists showed detectable effects on forskolin-induced cAMP production within a wide dosage range. This inability to detect any activation or inhibition of adenylyl cyclase in response to a wide variety of agonists was also observed in NIH 3 T3 cells expressing the $\mathrm{Ap5}-\mathrm{HT}_{\mathrm{BI}}$ receptor (data not shown). We then measured intracellular accumulation of inositol phosphates in the receptor expressing 293 cells after treatment with these same agonists (Fig. 3A). We found there is a significant increase in accumulation for both receptors in response to $0.1 \mu \mathrm{M} 5-\mathrm{HT}$, while similar concentrations of octopamine, histamine, and dopamine failed to show any effect. A dose-response curve shows that the activation of phospholipase $\mathrm{C}$ by $\mathrm{Ap} 5-\mathrm{HT}_{\mathrm{B} 1}$ and $\mathrm{Ap5}-\mathrm{HT}_{\mathrm{B} 2}$ was saturable and reached a plateau at $100 \mathrm{nM} 5$-HT (Fig. $3 B$ ). The estimated $\mathrm{EC}_{50}$ for serotonin was $1.8 \pm 0.6 \mathrm{nM}$ for $\mathrm{Ap5}-\mathrm{HT}_{\mathrm{B} 1}$ and $1.5 \pm 0.2 \mathrm{nM}$ for $\mathrm{Ap} 5-\mathrm{HT}_{\mathrm{B} 2}$, respectively. In our control expcriment, unstransfected 293 cells did not respond to any of the tested transmitters at all the concentrations tested (Fig. $3 A, B$ ). In a separate experiment, a mock transfected cell line, which contained only expression vector without the inserted gene, showed no response to 5-HT at $100 \mu \mathrm{M}$ concentration (data not shown). We then tested the effects of different antagonists on these receptors. Methiothepin and spiperone, that are respectively $5-\mathrm{HT}_{1-2}$ and $5-\mathrm{HT}_{2}$ antagonists, both prevented the 5-HTdependent stimulation of phospholipase $\mathrm{C}$ at $10 \mu \mathrm{M}$ concentra- tion. Cyproheptadine, which antagonizes both 5-HT, and 5- $\mathrm{HT}_{2}$ receptors in mammals and is used traditionally in Aplysia studies as well, did not affect the activation of the two receptors by 5-HT in our experiments at the same concentration (Fig. 4).

The Ap5-HT $T_{B 1}$ and Ap5-HT $T_{B 2}$ are differentially expressed in Aplysia $C N S$ and reproductive system

Northern blot analysis of poly(A) + mRNA extracted from various tissues of Aplysia, including the CNS, buccal muscle, liver, heart, and reproductive system, failed to detect any transcripts for both receptors (data not shown). We think this may be due to the low abundance of the receptor transcripts in any of these tissues. We therefore performed a more sensitive RT-PCR experiment on mRNA isolated from various tissues. To minimize experimental variations, a single oligonucleotide common to both receptor sequences was used for the reverse transcription. Similarly, a pair of sense and antisense primers common to both receptor sequences was used for the PCR reaction. This pair of primers was designed to amplify a region in which the two receptor sequences are divergent in size and sequence so that the signal specific for $\mathrm{Ap5}-\mathrm{HT}_{\mathrm{B} 1}$ or $\mathrm{Ap5}-\mathrm{HT}_{\mathrm{B} 2}$ can be readily distinguished. The PCR products were then analyzed by Southern blot. To avoid crosshybridization between the two receptor sequences or with other possible receptor sequences, 50-mer oligonucleotides with completely diverse nucleotide sequences taken from nonconserved regions of either receptor were used in the Southern blot hybridization reactions. An Ap5-HT $\mathrm{H}_{\mathrm{B} 1}$ fragment of 591 bp was detected in the spermatheca and the ovotestis. A 556 bp-long Ap5-HT ${ }_{\mathrm{B} 2}$-specific fragment was only detected in the CNS (Fig. 5). In the control experiment, no bands were detected when the reverse transcriptase was omitted (data not shown), indicating that the observed signal corresponds to mRNA instead of the contaminating genomic DNA.

Sequence encoding the Ap5-HT $\mathrm{B}_{\mathrm{B}} \mathrm{C}$-terminal intracellular segment was subcloned to produce fusion protein and the fusion protein was used to raise polyclonal antibodies. We then prepared crude tissue extracts from various Aplysia tissues, including buccal muscle, CNS, heart, and reproductive system. In the immunoblot analysis, a band of molecular weight $45 \mathrm{kD}$ was detected from the CNS and ovotestis, but not from the buccal muscle and heart (Fig. 6). The size of this band, $45 \mathrm{kD}$, corresponds to the predicted molecular weight of the Ap5-HT ${ }_{B 1}$ receptor. This band disappeared when the antibody was preabsorbed with the fusion protein antigen before use. Bands of higher molecular weight were also detected in all lanes. We think these bands may represent nonspecific antibody binding, since they still appeared after the antibody was preabsorbed with fusion protein antigen. Given the amino acid sequence homology between the two receptors-65\% identical within the C-terminal intracellular domain that was used to raise the antiserum-the polyclonal antibody raised against $\mathrm{Ap} 5-\mathrm{HT}_{\mathrm{B} 1}$ may well recognize both $\mathrm{Ap} 5-\mathrm{HT}_{\mathrm{B} 1}$ and $\mathrm{Ap5}-\mathrm{HT}_{\mathrm{B} 2}$ receptors as antigens. Since the expected molecular weights of the two receptors are quite close to one another $-45 \mathrm{kD}$ for Ap5- $\mathrm{HT}_{\mathrm{B} 1}$ and $42 \mathrm{kD}$ for Ap5$\mathrm{HT}_{\mathrm{B} 2}$ - they could not be readily resolved under our electrophoresis conditions. However, this Western blot analysis, together with the results of the RT-PCR experiment, suggest that the Aplysia serotonin receptor Ap5- $\mathrm{HT}_{\mathrm{B} 1}$ is expressed in the reproductive system and Ap5-HT $\mathrm{B}_{\mathrm{B} 2}$ is expressed in the nervous system. 

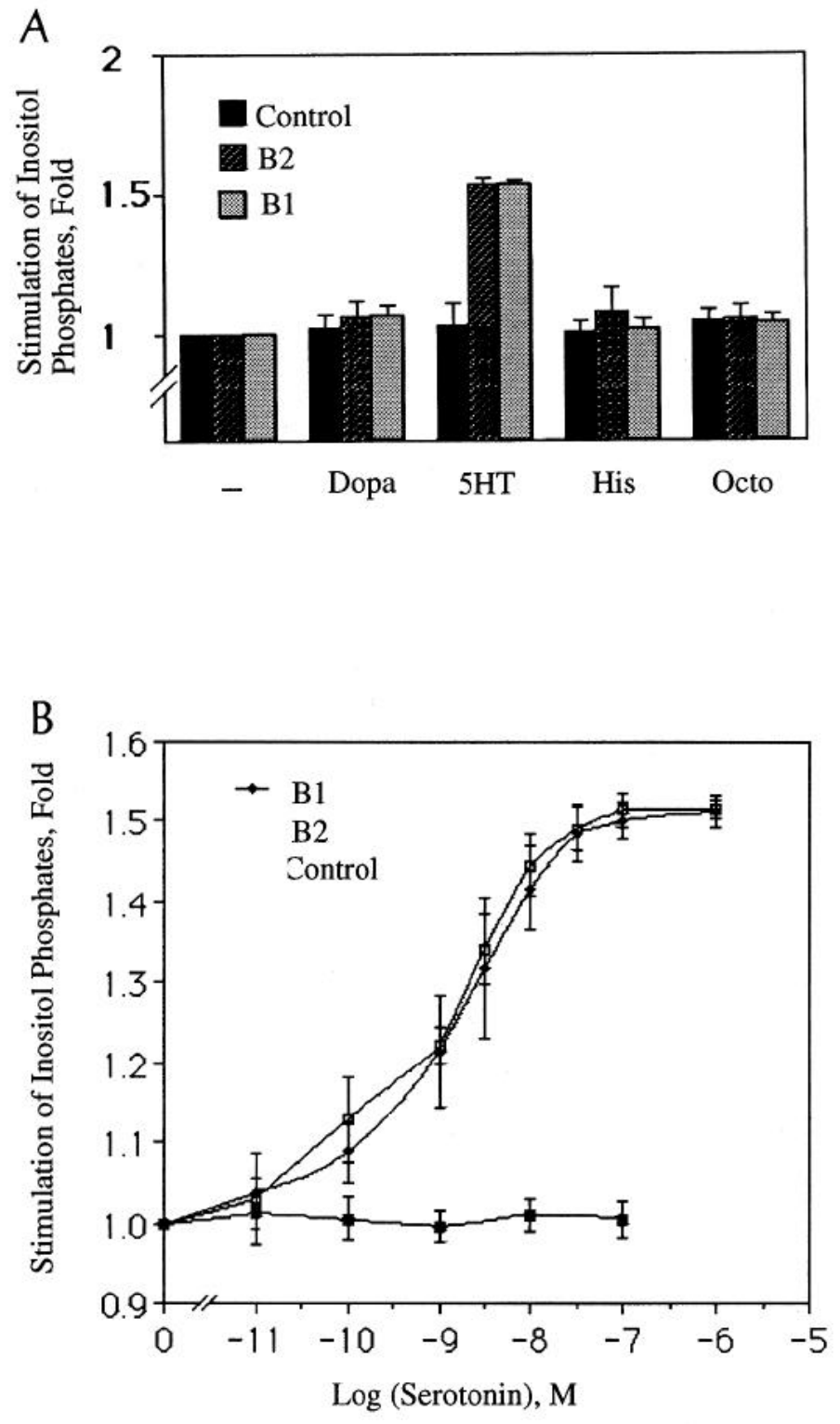

Figure 3. Pharmacological analysis of $\mathrm{Ap} 5-\mathrm{HT}_{\mathrm{B} 1}(B 1)$ and $\mathrm{Ap} 5-\mathrm{HT}_{\mathrm{B} 2}$ (B2) expressed in HEK-293 cells. A, Stimulation of inositol phosphates production in response to various neurotransmitters. Total intracellular IPs were assayed in transfected cells (B1 and B2) and nontransfected cells (control) in the absence $(-)$ and in the presence of $100 \mathrm{~nm}$ of dopamine (Dopa), serotonin (5-HT), histamine (Hist), and octopamine $($ Octo $)$. B , Concentration response curve for the stimulation of IPs production by 5-HT. In experiment A, the average basal levels of IPs for each cell line were $824 \pm 138 \mathrm{cpm} / 5 \times 10^{5}$ cells for the control 293 cell, $837 \pm 148 \mathrm{cpm} / 5 \times 10^{5}$ cells for B1, and $815 \pm 67 \mathrm{cpm} / 5 \times 10^{5}$ cells for B2. In experiment B, the average basal levels of IPs for each cell line were $618 \pm 106 \mathrm{cpm} / 5 \times 10^{5}$ cells for the control 293 cells, $680 \pm 136 \mathrm{cpm} / 5 \times 10^{5}$ cells for B1, and $698 \pm 148 \mathrm{cpm} / 5 \times 10^{5}$ cells for B2. Since the basal levels of each cell line were equivalent in each experiment, data were normalized relative to the basal levels and expressed as folds of stimulation. Data are represenatives of three independent experiments, each conducted in triplcate.

\section{Discussion}

We have described the isolation and characterization of two genomic clones that encode functional serotonin receptors of Aplysia californica. These two receptors are highly homologous to each other, sharing $80 \%$ sequence homology at the amino acid level. Both of them are intronless and contain seven putative

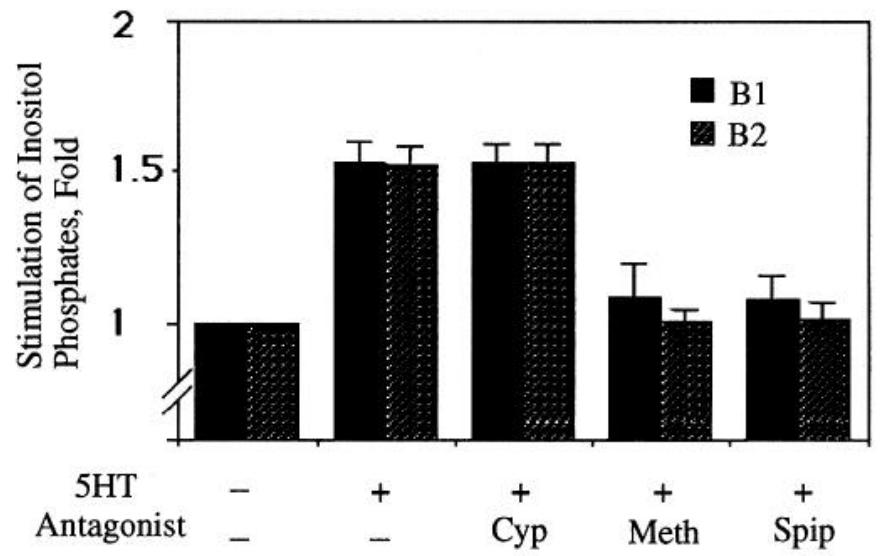

Figure 4. Effects of antagonists on serotonin stimulated inositol phosphate production. Total intracellular IPs in $A p 5-\mathrm{HT}_{\mathrm{B} 1}(B 1)$ and Ap5$\mathrm{HT}_{\mathrm{B} 2}$ (B2) transfected cells were assayed in the absence (-) and in the presence of $100 \mathrm{nM}$ serotonin and $10 \mu \mathrm{M}$ each of cyproheptadine $(C y p)$, methiothepin $(\mathrm{Meth})$, and spiperone $(\mathrm{Spi})$, respectively. The average basal levels of IPs were $823 \pm 201 \mathrm{cpm} / 5 \times 10^{5}$ cells for B1 and 876 $\pm 57 \mathrm{cpm} / 5 \times 10^{5}$ cells for B2. The subsequent experimental data were normalized as compared to the basal levels and expressed as fold of stimulation. Data are representatives of three experiments, each of which was conducted in triplicate.

transmembrane domains. Both of these receptors are coupled to phospholipase $\mathrm{C}$ to stimulate inositol phosphate metabolism. This coupling is dose dependent, saturable, and can be blocked by specific 5-HT antagonists such as methiothepin and spiperone. Sequence analysis shows that these two Aplysia serotonin receptors share various degrees of homology with other G-protein coupled serotonin receptors, especially within their transmembrane regions. However, the Aplysia receptors seem to represent a new subgroup, since they are not readily grouped within any of the other previously described mammalian and invertebrate serotonin receptors based on amino acid sequence homology.

\section{B1}

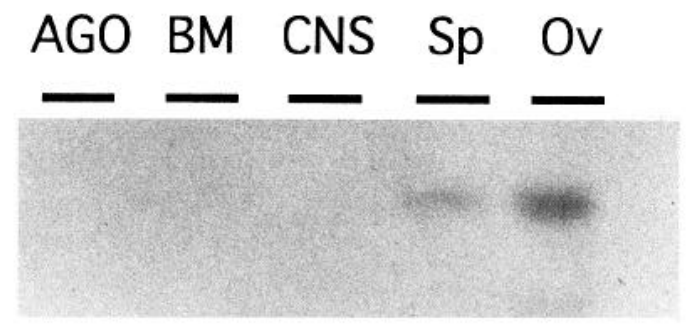

B2

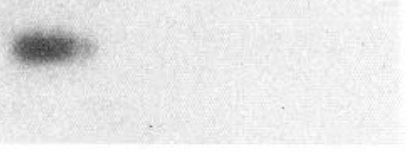

Figure 5. Distribution of $\mathrm{Ap} 5-\mathrm{HT}_{\mathrm{B} 1}$ and $\mathrm{Ap} 5-\mathrm{HT}_{\mathrm{B} 2}$ transcripts. RTPCR analysis was performed with $100 \mathrm{ng}$ of poly(A)+ RNA isolated from accessory genital organ (AGO), buccal muscle $(B M)$, CNS $(C N S)$, spermatheca $(S p)$, and ovotestis $(O v)$. The PCR products were analyzed by Southern blotting and the same blot was separately probed with an Ap5- $\mathrm{HT}_{\mathrm{B} 1}-$ specific or an Ap5- $\mathrm{HT}_{\mathrm{B} 2}$-specific oligonucleotide. The sizes of the RT-PCT bands were estimated by comparison with the DNA size markers on the original EtBr stained gel and the positive control, where the genomic clones Ap5- $\mathrm{HT}_{\mathrm{B} 1}$ and $\mathrm{Ap5}-\mathrm{HT}_{\mathrm{B} 2}$ were used as templates for PCR reactions. The 591 and 556 bp PCR products correspond respectively to the Ap5- $\mathrm{HT}_{\mathrm{B} 1}$ and $\mathrm{Ap} 5-\mathrm{HT}_{\mathrm{B} 2}$ mRNA. 
A
BM CNS Hrt Ove

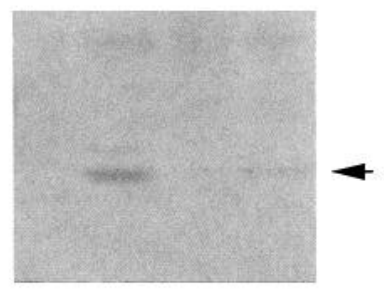

$\begin{array}{llll}1 & 2 & 3 & 4\end{array}$

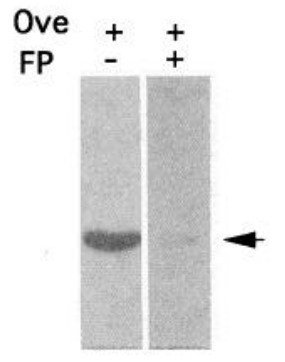

$1 \cdot 2$
Figure 6. Western Blot analysis of the expression of Ap5- $\mathrm{HT}_{\mathrm{B} 1}$ and Ap5- $\mathrm{HT}_{\mathrm{B} 2}$ receptors in different Aplysia tissues. A, Tissue homogenates were prepared from various Aplysia tissues, buccal muscle $(B M), \mathrm{CNS}$ $(\mathrm{CNS})$, heart ( $\mathrm{Hrt}$ ), and ovotestis (Ove). An equal amount of each homogenate was resolved by electrophoresis and analyzed by immunoblotting with antiserum raised against the Ap5-HTB1 C-terminal intracellular domain. The antibody probably did not discriminate between the two receptors due to the sequence homology shared between their C-terminal domains. $B$, Immunostaining of the $45 \mathrm{kd}$ band can be blocked by preincubation of the antiserum with the immunogenic fusion protein. FP stands for fusion protein, the antigen used to generate antibody.

The successful coupling between Aplysia receptors and mammalian phospholipase $\mathrm{C}$ suggests that the G-protein mediated phosphoinositol signaling pathway is well conserved throughout evolution. Surprisingly, these Aplysia receptors display a higher amino acid sequence homology to the mammalian $5-\mathrm{HT}_{1}$ receptors that are coupled to adenylyl cyclase than to the mammalian $5-\mathrm{HT}_{2}$ receptors that are coupled to phospholipase C. Therefore, despite their coupling to a common second messenger, the Aplysia receptors $\mathrm{Ap} 5-\mathrm{HT}_{\mathrm{B} 1}$ and $\mathrm{Ap} 5-\mathrm{HT}_{\mathrm{B} 2}$ do not appear to be the invertebrate homologs of the mammalian 5- $\mathrm{HT}_{2}$ receptors. It remain to be seen whether homologs of $5-\mathrm{HT}_{2}$ receptors exist in invertebrates.

Multiple receptor subtypes have emerged throughout evolution to execute a variety of physiological functions. In mammals, members of each receptor subfamily share structural and functional homology, but they often exhibit distinct pharmacological profiles and their expression patterns are under different controls. Interestingly, both Ap5- $\mathrm{HT}_{\mathrm{B} 1}$ and $\mathrm{Ap5}-\mathrm{HT}_{\mathrm{B} 2}$ receptors have similar pharmacological properties, but their expression patterns are markedly different. Ap5- $\mathrm{HT}_{\mathrm{B} 1}$ is expressed in the reproductive tissue, whereas Ap5- $\mathrm{HT}_{\mathrm{B} 2}$ is expressed in the nervous system. These two receptors might therefore result from the recent duplication of an ancestral gene, which placed the coding sequence of the ancestral gene under the control of totally different promoter sequences.

It is not unexpected for a 5-HT receptor to be expressed in the reproductive tract, since at least three nerves from the abdominal ganglion innervate it to control reproductive behavior. The genital and vulvar nerves innervate the reproductive duct and the spermatecal nerve goes to the spermatheca, presumably controlling some phases of egg and sperm movement. So far, no detailed physiological functions assigned to 5-HT have been described in the reproductive system of Aplysia.

The functions of serotonin receptors in the Aplysia nervous system have been studied in great detail. Serotonin can elicit both short-term and long-term facilitation between the identified sensory and motor neurons of the gill-withdrawal reflex. Early studies have shown that second-messenger-mediated protein kinases play key roles in synaptic facilitation. For example, cAMP-dependent protein kinase (PKA) activated by 5-HT can modulate ionic current, thereby modulating transmitter release. PKA also translocates into the nucleus presumably to initiate a cascade of gene expression (Pollock et al., 1985; Dash et al., 1990; Hochner and Kandel, 1992; Bacskai et al., 1993; Kaang et al, 1994).

Besides the PKA-signal transduction pathway, there is possibly a phospholipase C-PKC signaling pathway activated by the serotonin receptor in the sensory neuron itself. For example, serotonin activates a $\mathrm{Ca}^{2+}$-dependent $\mathrm{PKC}$ in sensory neurons (Sacktor and Schwartz, 1990; Sossin and Schwartz, 1992). The PKC activity contributes to facilitating neurotransmitter release, especially at the depressed synapse (Ghirardi et al., 1992). PKC also modulates $\mathrm{K}^{+}$currents, which contribute to spike broadening (Sugita et al., 1992, 1994).

Such diverse 5-HT responses can be attributed to the existence of multiple 5-HT receptors. For example, Mercer et al. (1992) and Emptage and Carew (1993) have reported pharmacological distinctions among different 5-HT receptors in sensory neurons. They reported that cyproheptadine, a 5-HT receptor blocker, selectively affects spike broadening and short-term facilitation without affecting membrane excitability and long-term facilitation.

The Ap5- $\mathrm{HT}_{\mathrm{B} 2}$ receptor is expressed in the Aplysia nervous system. It is coupled to phospholipase $\mathrm{C}$ and might therefore indirectly stimulate $\mathrm{PKC}$. The $\mathrm{Ap5}-\mathrm{HT}_{\mathrm{B} 2}$ receptor might therefore correspond to one of the receptors involved in modulation of synaptic plasticity, which are mentioned above. A detailed immunostaining study using the anti- $\mathrm{Ap} 5-\mathrm{HT}_{\mathrm{B} 2}$ antibody should tell us whether this receptor is expressed in sensory neurons or in other brain structures where 5-HT has been shown to play a role. In addition, the antibody and the antagonist that we characterized in this study might be used to manipulate the functions of this receptor in physiological studies. The availability of molecular probes for Aplysia 5-HT receptors should ultimately enable us to determine the contribution of individual 5-HT receptors to the numerous physiological functions modulated by $5-\mathrm{HT}$.

\section{References}

Alberini C, Ghirardi M, Metz R, Kandel ER (1994) C/EBP is an immediate-early gene required for the consolidation of long-term facilitation in Aplysia. Cell 76:1099-1114.

Bacskai BJ, Hochner B, Mahaut-Smith M, Adams SR, Kaang BK, Kandel ER, Tsien RY (1993) Spatially resolved dynamics of cAMP and protein kinase A subunits in Aplysia sensory neurons. Science 260: 222-226.

Baxter DA, Byrne JH (1990) Differential effects of cAMP and serotonin on membrane current, action-potential duration, and excitability in somata of pleural sensory neurons of Aplysia. J Neurophysiol 64: 978-990.

Blumenfeld H, Spira ME, Kandel ER, Siegelbaum SA (1990) Facilitatory and inhibitory transmitters modulate calcium influx during action potentials in Aplysia sensory neurons. Neuron 5:487-499.

Braha O, Dale N, Ho chner B, Klein M, Abrams TW, Kandel ER (1990) Second messengers involved in the two processes of presynaptic facilitation that contribute to sensitization and dishabituation in Aplysia sensory neurons. Proc Natl Acad Sci USA 87:2040-2044.

Dale N, Kandel ER (1990) Facilitatory and inhibitory transmitters modulate spontaneous transmitter release at cultured Aplysia sensorimotor synapses. J Physiol (Lond) 421:203-222.

Dash PK, Hochner B, Kandel ER (1990) Injection of cAMP-responsive 
element into the nucleus of Aplysia sensory neurons blocks long-term facilitation. Nature 345:718-721.

Drummond AH, Bucher F, Levitan IB (1980) Distribution of serotonin and dopamine receptors in Aplysia tissues: analysis by ("II)LSD binding and adenylate cyclase stimulation. Brain Res 184:163-177.

Emptage NJ, Carew TJ (1993) Long-term synaptic facilitation in the absence of short-term facilitation in Aplysia neurons. Science 262 : $253-256$

Gerschenfeld HM, Paupardin-Trich D (1974) Ionic mechanisms and receptor properties underlying the responses of molluscan neurones to 5-hydroxytryptamine. J Physiol (Lond) 243:427-456.

Ghirardi M, Braha O, Hochner B, Montarolo PG, Kandel ER, Dale N (1992) Roles of PKA and PKC in facilitation of evoked and spontaneous transmitter release at depressed and nondepressed synapses in Aplysia sensory neurons. Neuron 9:479 489 .

Gingrich KJ, Byrne JH (1985) Simulation of synaptic depression posttetanic potentiation and presynaptic facilitation of synaptic potentials for sensory neurons mediating gill-withdrawal reflex in Aplysia. $\mathbf{J}$ Neurophysiol 53:652-669.

Glanzman DL, Mackey SL, Hawkins RD, Dyke AM, Lloyd PE, Kandel ER (1989) Depletion of serotonin in the nervous system of Aplysia reduces the behavioral enhancement of gill withdrawal as well as the heterosynaptic facilitation produced by tail shock. J Neurosci 9:4200 4213.

Glanzman DL, Kandel ER, Schacher S (1990) Target-dependent structural changes accompanying long-term synaptic facilitation in Aplysia neurons. Science 249:799-802.

Hen R (1993) Structural and functional conservation of serotonin receptors throughout evolution. In: Comparative molecular neurobiology (Pichon T, ed), pp 266-278. Basel: Birkhäuser.

Hochner B, Kandel ER (1992) Modulation of a transient $\mathrm{K}^{+}$current in the pleural sensory neurons of Apylsia by serotonin and cAMP: implications for spike broadening. Proc Natl Acad Sci USA 89:1147611480.

Hochner B, Klein M, Schacher S, Kandel ER (1986) Additional component in the cellular mechanism of presynaptic facilitation contributes to behavioral dishabituation in Aplysia. Proc Natl Acad Sci USA 83:8794-8798.

Hoyer D, Clarke DE, Fozard JR, Hartig R, Martin GR, Mylecharane E, Saxena PR, Humphrey PPA (1994) Inernational union of pharmacology classification of receptors for 5-hydroxytryptamine (serotonin). Pharmacol Rev 46:157-203.

Julius D, McDermott AB, Axel R, Jessell TM (1988) Molecular char- acterization of a functional $\mathrm{cDNA}$ encoding the serotonin $1 \mathrm{c}$ receptor Science 241:558-564.

Julius D, Huang K, Livelli T, Axel R, Jessell T (1990) The $5 \mathrm{HT}_{2}$ receptor defines a family of structurally distinct but functionally con served serotonin receptors. Proc Natl Acad Sci USA 87:928-932.

Kaang B-K, Kandel ER, Grant SGN (1993) Activation of cAMP-responsive genes by stimuli that produce long-term facilitation in Aplysia sensory neurons. Neuron 10:427-435.

Kadan MJ, Hartig PR (1988) Autoradiographic localization and characterization of [ $\left.{ }^{125} \mathrm{I}\right]$ lyseric acid diethylamide binding to serotonin receptors in Aplysia. Neuroscience 24:1089-1102.

Kandel ER, Schwartz JH (1982) Molecular biology of learning: modulation of transmitter release. Science 218:433-443.

Klein M, Hochner B, Kandel ER (1986) Facilitatory transmitters and cAMP can modulate accommodation as well as transmitter release in Aplysia sensory neurons: evidence for parallel processing in a single cell. Proc Natl Acad Sci USA 83:7994-7998.

Maricq AV, Peterson AS, Brake AJ, Myers RM, Julius D (1991) Primary structure and functional expressiohn of the $5 \mathrm{HT} 3$ receptor, a serotonin-gated ion channel. Science 254:432-436.

Mercer AR, Emptage N., Carew TJ (1991) Pharmacological dissociation of modulatory effects of serotonin receptors in Aplysia sensory neurons. Science 254:1811-1813.

Sacktor TC, Schwartz, JH (1990) Sensitizing stimuli cause translocation of protein kinase $\mathrm{C}$ in Aplysia sensory neurons. Proc Natl Acad Sci USA 87:2036-2039.

Sawada M, Clcary LJ, Byrne JH (1989) Inositol triphosphate and activators of protein kinase $\mathrm{C}$ modulate membrane currents in tail motor neurons of Aplysia. J Neurophysiol 61:302-310.

Siegelbaum S, Cannardo JS, Kandel ER (1982) Serolonin and cAMP close single $\mathrm{K}^{+}$channels in Aplysia sensory neurones. Nature 299 413-417.

Sossin WS, Schwartz JH (1992) Selective activation of $\mathrm{Ca}^{2+}$-activated PKCs in Aplysia neurons by 5-HT. J Neurosci 12:1160-1168.

Sugita S, Goldsmith JR, Baxter DA, Byrne JH (1992) Involvement of protein kinase $\mathrm{C}$ in serotonin-induced spike broadening and synaptic facilitation in sensorimotor connections of Aplysia. J Neurophysiol 68:643-651

Sugita S, Baxter DA, Byrne JH (1994) Activators of protein kinase C mimic serotonin-induced modulation of a voltage-dependent potas sium current in pleural sensory neurons of Aplysia. J Neurophysiol $72: 1240-1249$

Wilkinson LO, Dourish CT (1991) Serotonin and animal behavior. In: Serotonin receptor subtypes; basic and clinical aspects (Peroutka $\mathrm{S}$, ed), pp 147-210. New York: Wiley. 